\title{
David Oliver: Let's streamline NHS bureaucracy and then leave it well alone
}

\author{
David Oliver consultant in geriatrics and acute general medicine
}

Berkshire

The House of Lords' recent report, The Long-Term Sustainability of the NHS and Adult Social Care, is a considered document, full of prescient evidence. ${ }^{1}$ Its recommendations include increasing NHS and social care funding, ringfencing public health budgets, and establishing an independent Office for Health and Care Sustainability. Overall, the report is a fairly sound and depoliticised template for the future.

But I have no confidence that the recommendations will be heeded. No government has had the courage to take a tax funded NHS out of partisan politics in the way that decisions on interest rates were delegated to an independent Bank of England committee. So long as the NHS is subject to the electoral cycle, ministers will always be tempted to mess with it—what some have called "NHS re-disorganisation." This ignores lessons on improving performance in health systems, that structure is secondary. It's not organisational charts that count-it's the people. $^{2}$

The Lords committee was clear that the Health and Social Care Act 2012 has created a fragmented system that frustrates efforts to integrate and transform care. The Lords also recommended merging NHS England and NHS Improvement to achieve more consistency in efficiency and performance. Such changes might require further, time consuming legislation.

Commissioning, the internal market, and the purchaser-provider split have not conspicuously succeeded, and they have added considerable costs to the system. ${ }^{3}$ The creation of these national bodies was a consequence of Andrew Lansley's rhetorical, grandstanding drive to "reduce bureaucracy"-despite the NHS needing good operational and financial managers and not being notably over-managed, compared with some systems. ${ }^{45}$

So long as the NHS is subject to the electoral cycle, ministers will always be tempted to mess with it

Lansley's changes stripped out vital experience and institutional memory, gave the commissioning function to new bodies, and left the NHS without strong regional oversight. ${ }^{6}$ Yet the 2012 act led to increasingly complex and impenetrable bureaucracy understood by few frontline staff or people outside the health policy community. ${ }^{78} \mathrm{NHS}$ England has drifted miles from its stated remit, NHS Improvement is involved in overlapping activities and sometimes conflicting messages or approaches, and the health secretary is far from the arm's length figure, uninvolved in the system's operation, originally envisaged by Lansley. ${ }^{910}$

There is real danger that people excited by re-drawing charts and creating new bodies think that this solves the NHS's real and pressing problems. I would suggest that services need adequate funding and a sufficient workforce, as well as a long period of stability with no further reorganisations to distract healthcare staff from improving frontline care.

By all means, let's merge a national body or two and streamline the NHS's hull. But then could we please stop rearranging the deckchairs in an NHS that risks sinking like the Titanic?

Competing interests: See www.bmj.com/about-bmj/freelancecontributors/david-oliver.

Provenance and peer review: Commissioned; not externally peer reviewed.

Follow David on Twitter: @mancunianmedic

House of Lords Select Committee on the Long-Term Sustainability of the NHS. Report of session 2016-17: the long-term sustainability of the NHS and adult social care. Apr 2017. https:/www.publications.parliament.uk/pa/ld201617/ldselect/ldnhssus/151/151.pdf.

2 Bohmer RMJ. The hard work of health care transformation. N Engl J Med 2016;357:709-11. www.nejm.org/doi/full/10.1056/NEJMp1606458. doi:10.1056/NEJMp1606458 pmid: 27557297.

3 Paton C. At what cost? Paying the price for the market in the English NHS. Centre for Health and the Public Interest. 2014. https://chpi.org.uk/wp-content/uploads/2014/02/Atwhat-cost-paying-the-price-for-the-market-in-the-English-NHS-by-Calum-Paton.pdf.

4 House of Lords Hansard. NHS: white paper. 12 Jul 2010. https://hansard.parliament.uk/ Lords/2010-07-12/debates/1007125000371/NHSWhitePaper.

5 King's Fund. Myth four: the NHS has too many managers. 1 Jun 2011. https://www. kingsfund.org.uk/topics/nhs-reform/mythbusters/nhs-managers.

6 Mason R, Walker P. NHS England chief hits back at Theresa May on health service funding. Guardian 11 Jan 2017. https://www.theguardian.com/society/2017/jan/11/nhsengland-chief-executive-simon-stevens-funding-theresa-may-public-accounts-committee. Timmins N. King's Fund, Institute for Government. Never again? The story of the Health and Social Care Act 2012. 2012. https://www.kingsfund.org.uk/sites/files/kf/field/field_ publication_file/never-again-story-health-social-care-nicholas-timmins-jul12.pdf.

8 King's Fund. An alternative guide to the new NHS in England. 2016. https://www.kingsfund. org.uk/projects/nhs-65/alternative-guide-new-nhs-england.

9 Oliver D. David Oliver: Nurse staffing levels are still not safe. BMJ 2016;357:i2665. doi 10.1136/bmj.i2665 pmid:27177770.

10 NHS England. Simon Stevens speech to NHS Confederation conference 2016. 20 Jun 2016. https://www.england.nhs.uk/2016/06/simon-stevens-confed-speech/. 
Published by the BMJ Publishing Group Limited. For permission to use (where not already granted under a licence) please go to http://group.bmj.com/group/rights-licensing/

permissions 